\title{
3-D cave mapping in the paleokarst region of Batu Katak in Northern Sumatra, Indonesia
}

Angel A. Acosta-Colón ${ }^{1}$, Benny X. Bonet-Santiago 2 , Ruddy Anto Sinulingga 3 , Sedarta Sitepu3

i Physics and Chemistry Department, University of Puerto Rico at Arecibo, Arecibo, PR (angel.acosta2@ Uupr.edu)

2 Biology Department, Universtty of Puerto Rico at Humacao, Humacho, PR (Benny.bonet@upr.edu)

3 Harmau Conservation, San Juan, PR

\section{Why Batu Katak?}

The Batu Katak village in Northern Sumatra, Indonesia lies in a karst forest. A group of scientists from the University of Puerto Rico with Harimau Conservation Organization explored the karst forest to find caves as a conservation action to protect the region and its geological importance. The unprotected karst forest is located next to the Gunung Leuser National Park (UNESCO World Heritage Site). This region is impacted with palm oil farms and possible mining. Our main goal was to create caves maps to be used for sustainable ecotourism and to understand the karst biodiversity including trogloxenes species such as bats, snakes, cave swallows, tigers and many more.

\section{Cave Cartography Method}

Light Detection And Ranging (LiDAR) was used to create 3-D cave maps. The Geoslam ZEBi (3-D Laser Mapping) hand held mobile LiDAR was used to obtain the measurements. Mobile laser scanning system that uses relative measurements to the environment that travels. The system maps the area in around the same time it takes to walk. The data acquisition speed is 43,200 pts/s with a range of $30 \mathrm{~m}$. The field of view: $270^{\circ}$ by $100^{\circ}$ and its source is a $905 \mathrm{~nm}$ laser diode (infra-red). The data and its source is a processing consists in that the system estimate the trajectory (position and orientation

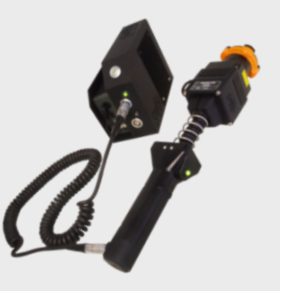

\section{Geologic Setting of Batu Katak}

The Batu Katak village in Northern Sumatra, Indonesia is located in the Batumilmil formation (Bachtiar et. al., 2014), a paleokarst that consist in dark gray to reddish gray limestone. By understanding the cave characteristics, can be concluded that the caves were created in an ancient karstification (paleokarst). Recent karstification processes is occurring and creating stalactite and stalagmites (new calcite deposition) in most of the caves.
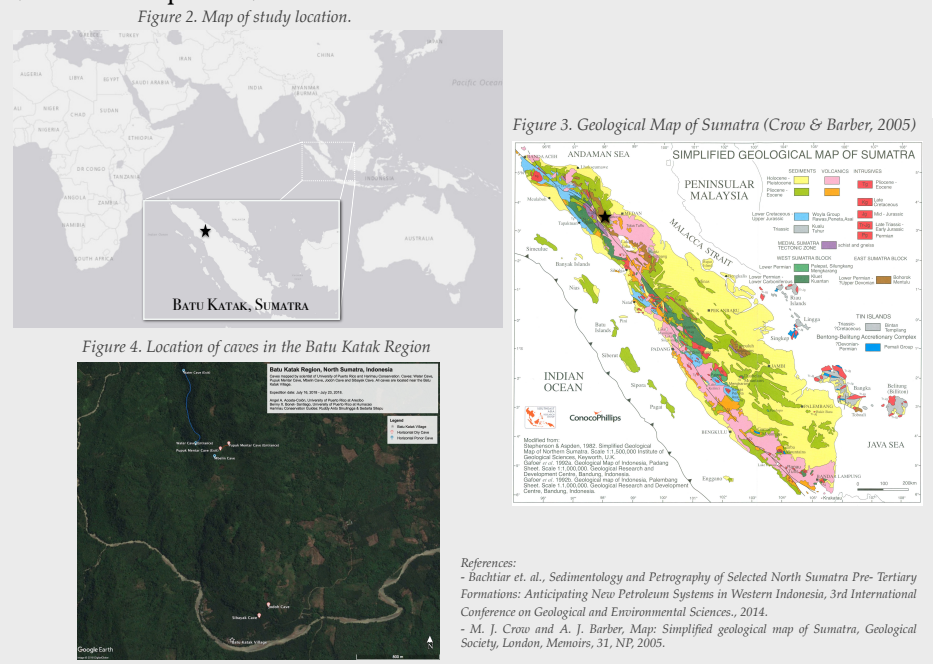

Jodoh Cave

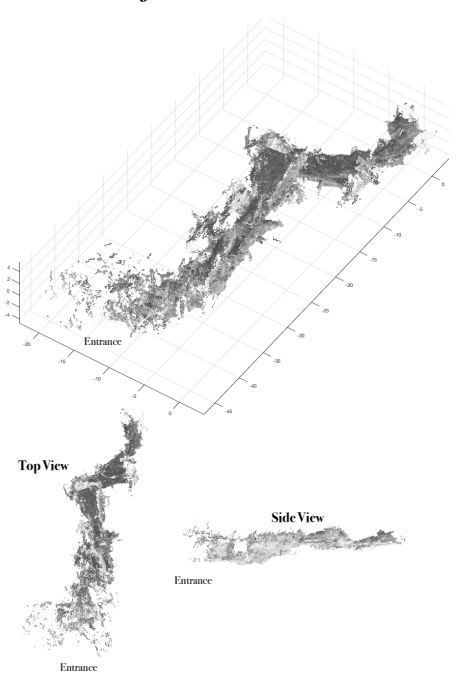

Pupuk Mentar Cave
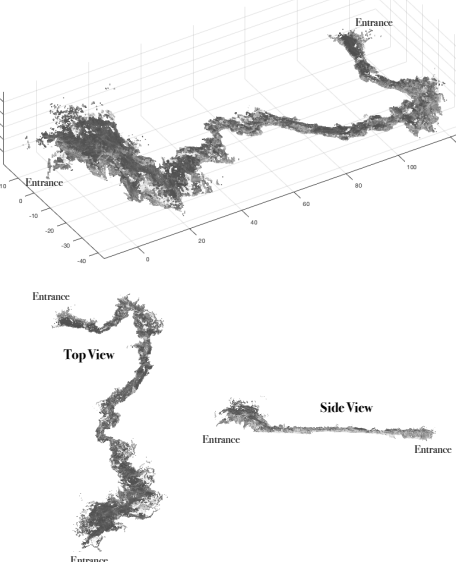

\section{Cave Enviroment} $\begin{array}{lccc}\text { Cave Name } & \begin{array}{c}p H \\ \text { (inside/outside) }\end{array} & \begin{array}{c}\text { Temperature }\left({ }^{\circ} \mathrm{C} \text { ) }\right. \\ \text { (inside/outside) }\end{array} & \begin{array}{c}\text { Relative Humidity \% } \\ \text { (inside/outside) }\end{array} \\ \text { Water Cave } & 7.85 / 8.06 \text { (water) } & 22.8 / 23.5 & 94.2 / 88.0\end{array}$ $\begin{array}{lll} & 7.85 / 8.06 \text { (water) } & 22.8 / 23.5 \\ \text { Pupuk Mentar Cave } & 7.85 / 7.95 \text { (water) } & 23.3 / 24.2\end{array}$ $\begin{array}{lrr}\text { Mbelin Cave } & 8.39 / 8.21 \text { (water) } & 22.8 / 22.9 \\ \text { Sibayak Cave } & 5.16 / 7.88 \text { (soil) } & 23.9 / 24.7\end{array}$ Sibayak Cave Jodoh Cave
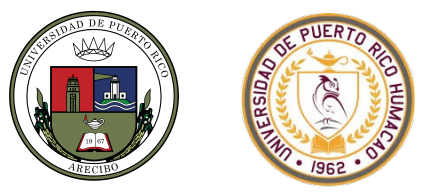

\section{Cave Cartography Results}

Sibayak Cave

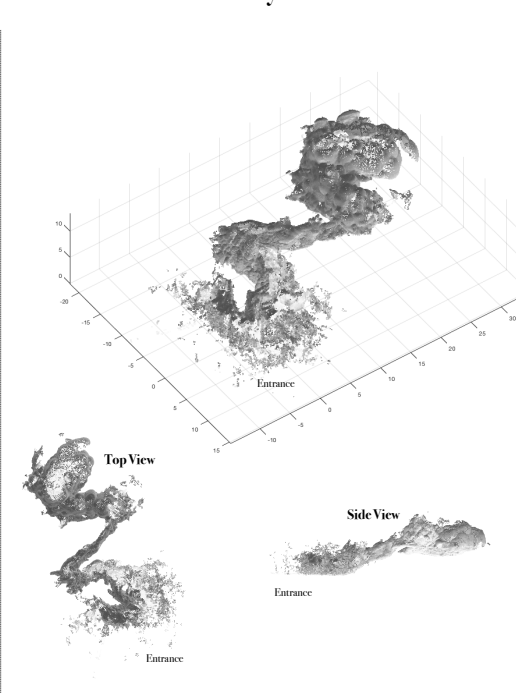

Water Cave
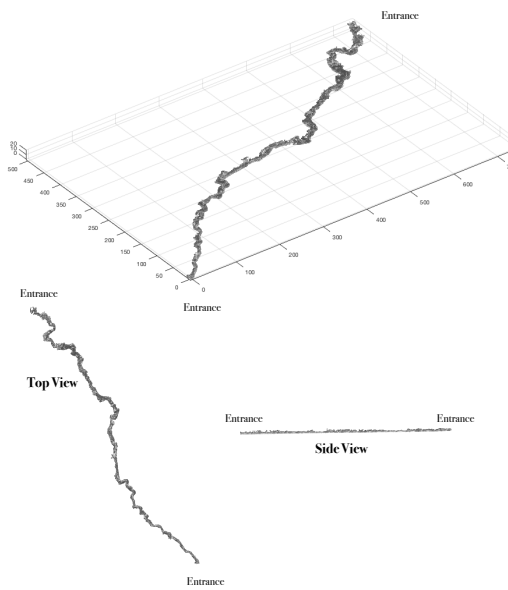

Mbelin Cave

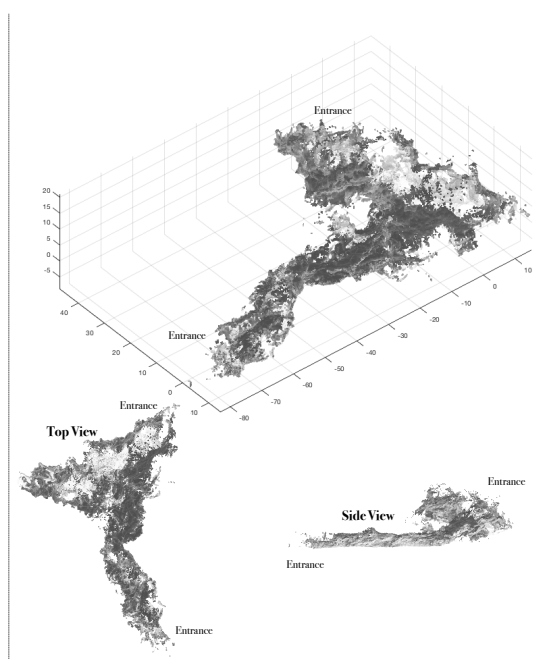

Table 1. Summary of the Cave Cartography Results

\begin{tabular}{lccc|} 
Cave Name & $\begin{array}{c}\text { Data } \\
\text { Collected } \\
\text { (in Millions) }\end{array}$ & $\begin{array}{c}\text { Mapping Data } \\
\text { 9\% reduction } \\
\text { (in Millions) }\end{array}$ & $\begin{array}{c}\text { Length } \\
\text { (m) }\end{array}$ \\
Water Cave & 65.5 & 59.5 & 901 \\
\hline Pupuk Mentar Cave & 25.2 & 22.9 & 121 \\
\hline Mbelin Cave & 17.3 & 15.7 & 100 \\
\hline Sibayak Cave & 11.2 & 10.2 & 36 \\
\hline Jodoh Cave & 7.48 & 6.8 & 45
\end{tabular}

The Batu Katak region consists of 5 caves (Figure 4): Water Cave, Pupuk Mentar Cave, Mbelin Cave, Sibayak Cave and Jodoh Cave. For the first time, westerners were allowed to study the caves. A total of $1.2 \mathrm{Km}$ were cartographied and 126.6 Millions data points collected. The maps created can be used to develop ecotourism guided routes, cave safety management and develop mitigation plans for karst biodiversity and land protection, among others.

Cave enviromental parameters consisted of insitu measurements of water or soil $\mathrm{pH}$, temperature and relative humidity for the different caves. We used a Extech $\mathrm{pH}$ module and Delmhorst thermo-hygrometer. These parameters can provide us with information about water safety, cave enviroment and conditions for the posibility of ecotourism.

Acknowledgements: The authors want to thanks Harimau Conservation for the support and organization of the Sumatra expedition and surveys for this study. Aditionally, B. Bonet-Santiago want to thanks PR-LSAMP for the travel scholarship for this presentation. Funding for this study was provided by MSEIP-
P120A110098 project at UPR-A. 